\title{
Seed development of arrowleaf, balansa, gland and Persian clover
}

\author{
H. NORI ${ }^{1}$, D.P. MONKS ${ }^{2}$ and D.J. MOOT ${ }^{3}$ \\ ${ }^{1}$ Faculty of Resource Science and Technology, Universiti Malaysia Sarawak, Malaysia. \\ ${ }^{2}$ Department of Environment and Primary Industries, Victoria, Australia. \\ ${ }^{3}$ Faculty of Agriculture and Life Sciences, Lincoln University, Canterbury, New Zealand. \\ nhollena@frst.unimas.my
}

\begin{abstract}
The development process from floral bud formation to seed maturity of four top flowering annual clovers was quantified from a field experiment across 10 sowing dates at Lincoln University, Canterbury, New Zealand. For each species, a numeric reproductive scale was created as a field guide to document morphological changes as the bud progresses through reproductive development. The duration from bud visible to open flower was $341{ }^{\circ} \mathrm{C}$ days for 'Cefalu' arrowleaf, 215 ${ }^{\circ} \mathrm{C}$ days for 'Bolta' balansa, $196{ }^{\circ} \mathrm{C}$ days for 'Prima' gland and $186{ }^{\circ} \mathrm{C}$ days for 'Mihi' Persian clover. The inflorescence then required a further $274-689{ }^{\circ} \mathrm{C}$ days, $185{ }^{\circ} \mathrm{C}$ days, $256{ }^{\circ} \mathrm{C}$ days and $425{ }^{\circ} \mathrm{C}$ days for each respective species to reach physiological maturity. This was indicated when $50 \%$ of seeds had turned red/brown for 'Cefalu' arrowleaf, $100 \%$ pods turned yellow for 'Bolta' balansa, $100 \%$ of seeds were yellow and hard for 'Prima' gland, and pods turned brown with the first sign of colour change in seeds for 'Mihi' Persian clover. These results can be used to facilitate on farm decision making in relation to grazing management or seed set for subsequent regeneration.
\end{abstract}

Keywords: floral development chart, harvest maturity, peak flowering, pollination, seed filling, thermal time, Trifolium vesiculosum, T. michelianum, $T$. glanduliferum, T. resupinatum

\section{Introduction}

In annual crops, flower initiation is critical because it marks the starting point for reproductive development towards crop maturity and completion of their life cycle. The process of legume flowering begins when the shoot at the main stem changes from producing new young leaves to producing a flower bud. These flower buds will form an inflorescence and these will develop into seed pods. However, in a population of plants, pollination and seed maturity do not occur within a uniform time period. To determine a suitable time for seed harvest or re-introduce livestock for grazing, farmers need to know the majority of seeds are physiologically mature. This is because harvesting before physiological maturity may result in immature seeds with reduced seed quality and germination (Samarah 2006). Late harvest risks seed yield losses due to seed shattering
(Siddique \& Wright 2003). Thus, a biological indicator of physiological maturity is required to indicate harvest time. Maximum seed dry weight is a commonly used parameter to define seed physiological maturity, with the assumption that seed filling has ended at this phase (Hyde 1950). Evaluation of physiological maturity based on maximum seed dry weight has been conducted on various legume crops such as peas (Pisum sativum) (Deunff \& Rachidian 1988), and white lupin (Lupinus albus) (Clapham \& Barnes 1990), and will be used in this study to determine seed maturity in annual clovers. Under field conditions, seed morphological appearance at maturity can be tracked by using a visual reproductive development scale. Development scales are numbered in the order of ontogenetical stages of appearance, as inflorescence progresses from bud visible to seed maturity. Each ontogenetical stage is identified with a field observable picture and brief description. For cereals, the Zadoks code (Zadoks et al. 1974) documents developmental stages from germination to seed ripening. Similarly, a development scale for several legume cash crops has been developed (e.g. pea (Knott 1987) and recently Monks (2009) generated a reproductive development scale for balansa clover (Trifolium michelianum). This describes the progress of individual inflorescence from bud visible to seed shatter, and this scale will be used to track reproductive development of balansa clover and to generate a similar scale for arrowleaf (T. vesiculosum), gland (T. glanduliferum) and Persian (T. resupinatum) clovers. Thus, this study aims to quantify the duration of seed development (from bud visible to physiological maturity) based on the generated reproductive development scale of these four species of annual clovers.

\section{Materials and methods}

Four replicates of 'Cefalu' arrowleaf, 'Bolta' balansa, 'Prima' gland and 'Mihi' Persian clover were sown at Lincoln University, Canterbury, New Zealand ( $43^{\circ} 38^{\prime} \mathrm{S}$, $172^{\circ} 28^{\prime} \mathrm{E}, 11 \mathrm{~m}$ a.s.1.) on 10 dates at monthly intervals (Table 1). The experimental design was a split-plot factorial in randomised complete blocks with sowing date as main plots and species as sub-plots $(3 \times 2 \mathrm{~m})$. Information on the site location and crop management were described previously by Nori et al.(2014). In this location, monthly rainfall ranged from $153 \mathrm{~mm}$ in 
May 2010 to $9 \mathrm{~mm}$ in November 2009 (Figure 1). The mean daily air temperature ranged from $5.6^{\circ} \mathrm{C}$ (July 2010 ) to $16.8^{\circ} \mathrm{C}$ in December 2010. Unscarified seeds of annual clovers were sown as monoculture at $6 \mathrm{~kg} /$ ha ('Cefalu' arrowleaf), $4 \mathrm{~kg} / \mathrm{ha}$ ('Bolta' balansa and 'Prima' gland) and $5 \mathrm{~kg} / \mathrm{ha}$ ('Mihi' Persian) based on the final germination tests and seed weight data. The aim was to produce a monoculture of each species (at ca. 400 seedlings $/ \mathrm{m}^{2}$ ) that could be used to monitor plant development. Air temperature was recorded from a sensor placed at $1.2 \mathrm{~m}$ above the ground. Plots were not grazed throughout the crops' life span.

In each subplot, 10 plants were marked for detailed reproductive measurements. Date of flowering was

Table 1 The sowing dates and date of flowering for four species of annual clovers sown at Lincoln University, Canterbury, New Zealand.

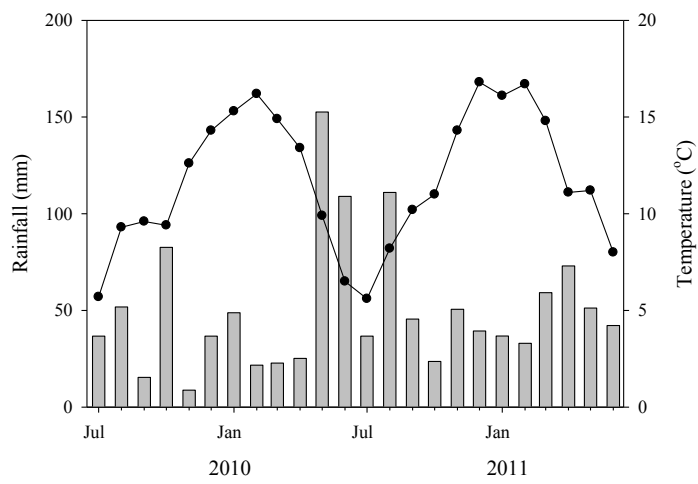

Figure 1 Monthly rainfall (bars) and mean daily air temperature $(\bullet)$ from 1 July 2009 to 30 June 2011. Data were obtained from Broadfields meteorological station (2 km north of the site), Canterbury, New Zealand.

\begin{tabular}{|c|c|c|c|c|}
\hline \multirow[t]{2}{*}{ Sowing date } & \multicolumn{4}{|c|}{ Date of flowering (first bud visible in $50 \%$ of marked plants) } \\
\hline & ‘Cefalu’ arrowleaf & 'Bolta' balansa & 'Prima' gland & 'Mihi' Persian \\
\hline $26 / 2 / 2010$ & $21 / 9 / 10$ & $14 / 9 / 10$ & $16 / 7 / 10$ & $16 / 11 / 10$ \\
\hline $30 / 3 / 2010$ & $16 / 10 / 10$ & $1 / 10 / 10$ & $9 / 9 / 10$ & $20 / 11 / 10$ \\
\hline $4 / 5 / 2010$ & $23 / 10 / 10$ & $8 / 10 / 10$ & $22 / 9 / 10$ & $20 / 11 / 10$ \\
\hline 3/6/2010 & $24 / 10 / 10$ & $15 / 10 / 10$ & $28 / 9 / 10$ & $22 / 11 / 10$ \\
\hline 7/7/2010 & $8 / 11 / 10$ & $22 / 10 / 10$ & $12 / 10 / 10$ & $23 / 11 / 10$ \\
\hline $14 / 8 / 2010$ & $19 / 11 / 10$ & $8 / 11 / 10$ & $29 / 10 / 10$ & $3 / 12 / 10$ \\
\hline $25 / 9 / 2010$ & $16 / 12 / 10$ & $6 / 12 / 10$ & $20 / 11 / 10$ & $16 / 12 / 10$ \\
\hline 9/11/2010 & $20 / 1 / 11$ & $31 / 12 / 10$ & $25 / 12 / 10$ & $5 / 2 / 11$ \\
\hline 20/12/2010 & $5 / 3 / 11$ & $10 / 2 / 11$ & $7 / 2 / 11$ & - \\
\hline $19 / 1 / 2011$ & $29 / 4 / 11$ & $31 / 3 / 11$ & $9 / 3 / 11$ & - \\
\hline
\end{tabular}

Each date of flowering is means of four replicates.

Table 2 Numeric scale outlining the ontogenetical progress of an arrowleaf clover inflorescence.

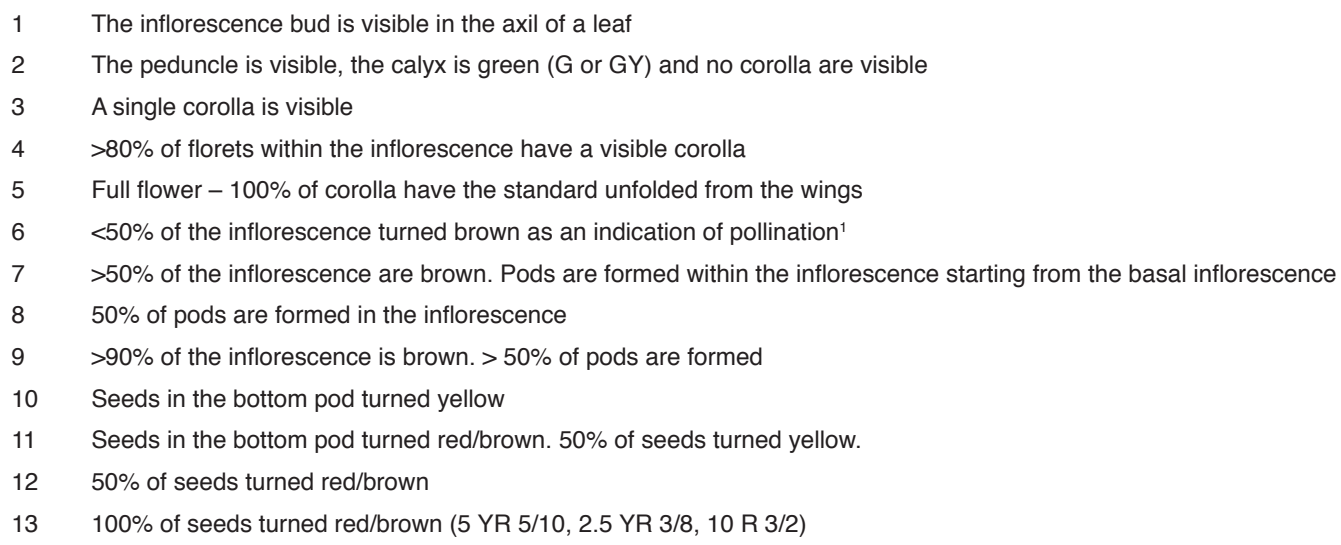


determined when $50 \%$ of the marked plants had their first inflorescence bud visible in the axil of a leaf. A reproductive development scale was generated with a numeric score that represented the ontogenetical changes in the inflorescence from bud visible to harvest maturity in arrowleaf, balansa, gland and Persian clovers. For balansa clover, the reproductive development scale was generated previously by Monks (2009) (Table 3) and was used to track seed development of balansa clover in this study. Meanwhile, the scales created for arrowleaf, gland and Persian clover inflorescences (Tables 2, 4 and 5) were based on Monks (2009) with modification to account for the different reproductive structures for each species.

One hundred inflorescences per subplot were tagged at the first sign of pollination (stage 6). Following inflorescence marking, five inflorescences were harvested at 4 day intervals. These were dissected and observed in detail using numeric scores from the reproductive development scale before dry weight measurement. Harvesting and recording stopped when $100 \%$ of seeds had turned red/brown (stage 13 for arrowleaf clover) and the seed pods had shattered (stage 16 for balansa, stage 13 for gland and stage

Table 3 Numeric scale outlining the ontogenetical progress of a balansa clover inflorescence.(From Monks 2009).

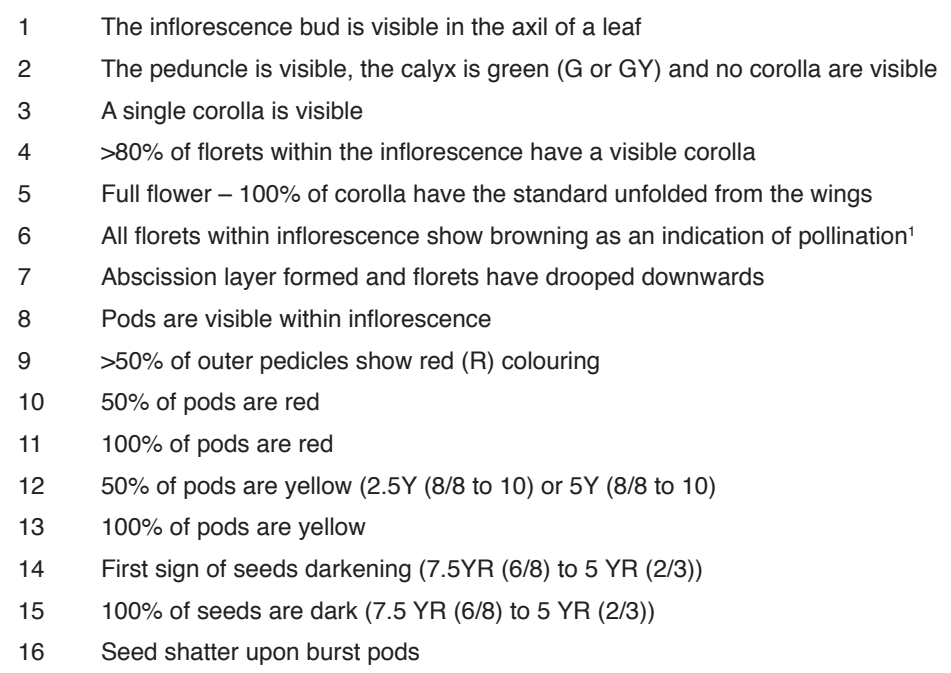

Note: Values within parentheses correspond to Munsell (1977) colour charts for plant tissues.

${ }^{1}$ Petals that are brown/wilted with age are not counted.For a revised scale, refer to Nori (2013).

Table $4 \quad$ Numeric scale outlining the ontogenetical progress of a gland clover inflorescence.

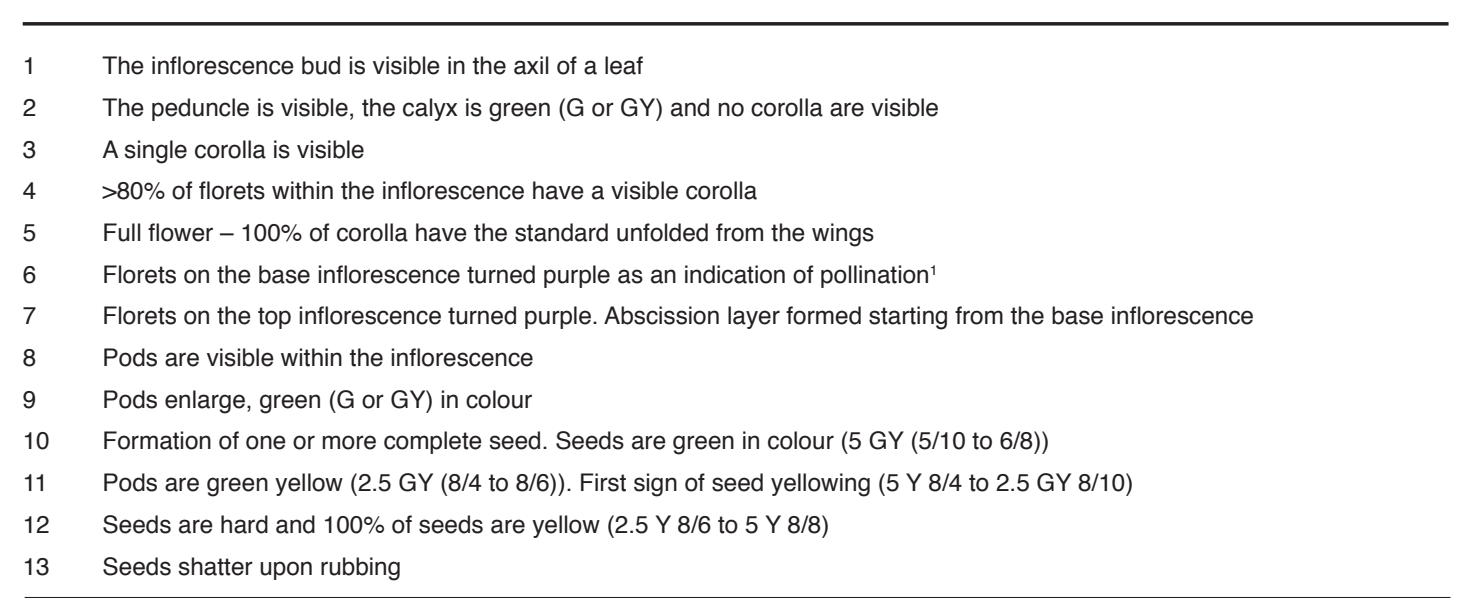


12 for Persian clover). The time from first floral bud visible to seed maturity was quantified using thermal time calculated using the equations in Jones \& Kiniry (1986). The dry weight of inflorescence was plotted against thermal time from pollination to determine physiological maturity of the seed. The maximum dry weight of the inflorescence marked seed physiological maturity (Hyde 1950). It was assumed that the increase in total inflorescence weight was reasonably related to the seed filling and that any decrease in dry weight (pod dessication, etc.) began at the time of seed maturity (Davies \& Williams 1986).

\section{Results}

Flowering occurred in all plots except for 'Mihi' Persian clover sown on 20 December 2010 and 19 January 2011. The plants sown on these dates died in August 2011, with no signs of reproductive development. The thermal

Table $5 \quad$ Numeric scale outlining the ontogenetical progress of a Persian clover inflorescence.

1 The inflorescence bud is visible in the axil of a leaf

2 The peduncle is visible, the calyx is green ( $\mathrm{G}$ or $\mathrm{GY}$ ) and no corolla are visible

3 A single corolla is visible

$4>80 \%$ of florets within the inflorescence have a visible corolla

5 Full flower $-100 \%$ of corolla have the standard unfolded from the wings

6 Florets turned brown as an indicator of pollination starting from the basal inflorescence ${ }^{1}$

7 All florets within the inflorescence turned brown

8 Inflorescence swell, pods start to form within the inflorescence

9 Pods enlarge, green in colour

10 Pods turned yellow. Seeds are green in colour

11 Pods turned brown. First sign of seeds change colour

12 Pods burst

Note: Values within parentheses correspond to Munsell (1977) colour charts for plant tissues.

${ }^{1}$ Petals that are brown/wilted with age are not counted. For a revised scale, refer to Nori (2013).

Table 6 Thermal time accumulation $\left({ }^{\circ} \mathrm{C}\right.$ days) from bud visible to open flower in 'Cefalu' arrowleaf, 'Bolta' balansa, 'Prima' gland and 'Mihi' Persian clovers sown on 10 different dates in Lincoln University, Canterbury, New Zealand.

\begin{tabular}{lcccc}
\hline Sowing date & \multicolumn{4}{c}{ Species } \\
\cline { 2 - 5 } & $\begin{array}{c}\text { 'Cefalu' } \\
\text { arrowleaf }\end{array}$ & $\begin{array}{c}\text { 'Bolta' } \\
\text { balansa }\end{array}$ & $\begin{array}{c}\text { 'Prima' } \\
\text { gland }\end{array}$ & $\begin{array}{c}\text { 'Mihi' } \\
\text { Persian }\end{array}$ \\
\hline 26/2/2010 & 341 & 237 & 214 & 210 \\
$30 / 3 / 2010$ & 369 & 215 & 219 & 204 \\
$4 / 5 / 2010$ & 366 & 230 & 216 & 208 \\
$3 / 6 / 2010$ & 354 & 227 & 198 & 180 \\
$7 / 7 / 2010$ & 326 & 237 & 218 & 172 \\
14/8/2010 & 304 & 197 & 184 & 163 \\
$25 / 9 / 2010$ & 303 & 190 & 181 & 167 \\
9/11/2010 & 327 & 206 & 167 & 182 \\
20/12/2010 & 378 & 192 & 175 & - \\
19/1/2011 & - & 222 & 185 & - \\
\hline Mean & 341 & 215 & 196 & 186 \\
S.E.M. & 7.4 & 4.5 & 5.2 & 6.4 \\
P-value & 0.148 & 0.059 & 0.175 & 0.430 \\
\hline
\end{tabular}

Thermal time quantified based on air temperature $\left(T_{b}=0^{\circ} \mathrm{C}\right)$. S.E.M., standard error of the mean.
Table 7 Inflorescence maximum dry weight (g) of 'Cefalu' arrowleaf, 'Bolta' balansa, 'Prima' gland and 'Mihi' Persian clovers sown on 10 different dates in Lincoln University, Canterbury, New Zealand.

\begin{tabular}{|c|c|c|c|c|}
\hline \multirow[t]{2}{*}{ Sowing date } & \multicolumn{4}{|c|}{ Species } \\
\hline & $\begin{array}{c}\text { 'Cefalu' } \\
\text { balansa }\end{array}$ & $\begin{array}{c}\text { 'Bolta' } \\
\text { arrowleaf }\end{array}$ & $\begin{array}{l}\text { 'Prima' } \\
\text { gland }\end{array}$ & $\begin{array}{l}\text { 'Mihi' } \\
\text { Persian }\end{array}$ \\
\hline 26/2/2010 & 0.73 & 0.28 & 0.10 & 0.11 \\
\hline $30 / 3 / 2010$ & 0.83 & 0.26 & 0.12 & 0.12 \\
\hline $4 / 5 / 2010$ & 0.94 & 0.27 & 0.12 & 0.11 \\
\hline 3/6/2010 & 0.71 & 0.21 & 0.13 & 0.11 \\
\hline 7/7/2010 & 0.70 & 0.20 & 0.12 & 0.10 \\
\hline $14 / 8 / 2010$ & 0.67 & 0.18 & 0.10 & 0.08 \\
\hline 25/9/2010 & 0.74 & 0.19 & 0.10 & 0.08 \\
\hline $9 / 11 / 2010$ & 0.64 & 0.14 & 0.11 & 0.07 \\
\hline 20/12/2010 & - & 0.13 & 0.10 & - \\
\hline $19 / 1 / 2011$ & - & - & - & - \\
\hline Mean & 0.74 & 0.21 & 0.11 & 0.10 \\
\hline S.E.M. & 0.029 & 0.009 & 0.003 & 0.004 \\
\hline P-value & 0.168 & $<.001$ & 0.017 & 0.008 \\
\hline L.S.D. (5\%) & - & 0.036 & 0.019 & 0.030 \\
\hline
\end{tabular}

S.E.M. standard error of the mean.L.S.D., Least significant differences 

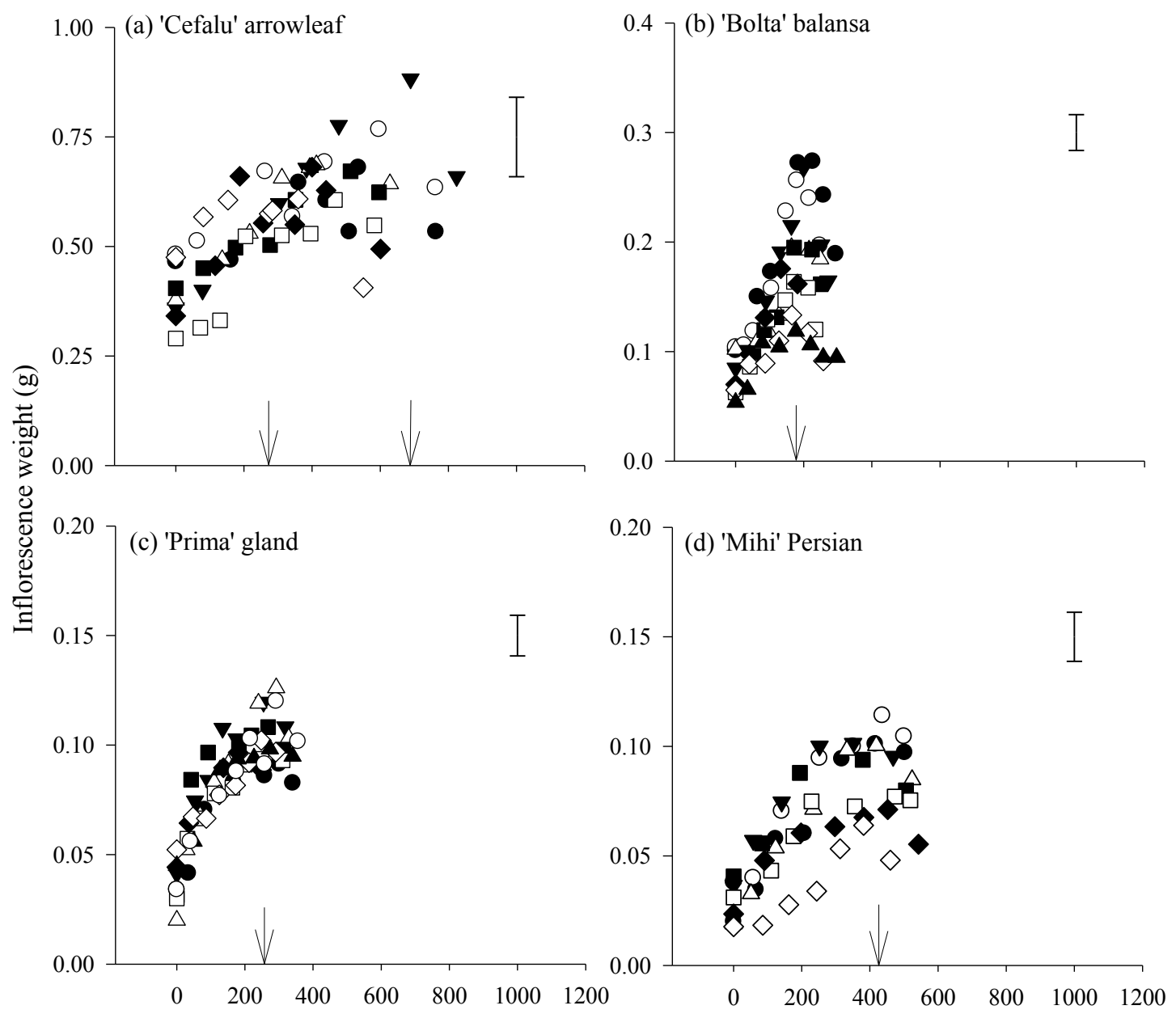

Thermal time from pollination $\left({ }^{\circ} \mathrm{C} \mathrm{d}\right)$

Figure 2 The inflorescence weight of (a) 'Cefalu' arrowleaf (b) 'Bolta' balansa (c) 'Prima' gland and (d) 'Mihi' Persian clovers against thermal time from pollination (stage 6) for crops sown on different dates at Lincoln University, Canterbury, New Zealand. 26 Feb $10(\bullet), 30$ Mar $10(\mathrm{O}), 4$ May $10(\boldsymbol{\nabla})$, 3 Jun $10(\triangle)$, 7 Jul $10(\mathbf{\square}), 14$ Aug $10(\square)$, 25 Sep $10(\diamond), 9$ Nov $10(\diamond), 20$ Dec $10(\Delta)$. Arrows indicate physiological maturity. Error bars represent the maximum standard error of the mean. Note: Thermal time analysis used air temperature $\left(T_{b}=0^{\circ} \mathrm{C}\right.$ for arrowleaf and Persian, $T_{b}=5.2^{\circ} \mathrm{C}$ for balansa and $\mathrm{T}_{\mathrm{b}}=4.3^{\circ} \mathrm{C}$ for gland clover (Nori et al. 2014)). For statistical results across 10 sowing dates, refer to Nori et al. (2014).

time accumulation from bud visible to open flower averaged $341{ }^{\circ} \mathrm{C}$ days for 'Cefalu' arrowleaf, $215^{\circ} \mathrm{C}$ days for 'Bolta' balansa, $196^{\circ} \mathrm{C}$ days for 'Prima' gland and $186^{\circ} \mathrm{C}$ days for 'Mihi' Persian clovers across all sowing dates (Table 6). 'Cefalu' arrowleaf clover sown on 19 January 2011 had visible buds on 29 April 2011 but these did not develop any further.

In all species, inflorescences for plants sown on 19 January 2011 rotted due to continuous autumn rainfall and lack of pollination in May 2011 and failed to reach physiological maturity (Table 7). The maximum weight of inflorescence in all species differed $(\mathrm{P}<0.05)$ with sowing date, except for 'Cefalu' arrowleaf clover.

The maximum weight of inflorescence in 'Cefalu' arrowleaf clover averaged $0.74 \mathrm{~g}$ across all sowing dates. For 'Bolta' balansa clover, the weight of inflorescence declined with successive sowing dates from $0.28 \mathrm{~g}$ for February sown plants that flowered in early spring to $0.13 \mathrm{~g}$ for December sown plants that flowered in mid-summer. The maximum weight of inflorescence in 'Prima' gland clover ranged from 0.10 to $0.13 \mathrm{~g}$. For 'Mihi' Persian clover, the maximum weight of inflorescence averaged $0.11 \mathrm{~g}$ for those that flowered in late spring (sown between February and June) but decreased with seasonal changes down to $0.07 \mathrm{~g}$ in late summer (November sown). The inflorescence reached its maximum weight (physiological maturity) after 274-689 ${ }^{\circ} \mathrm{C}$ days for 'Cefalu' arrowleaf, $185{ }^{\circ} \mathrm{C}$ days for 'Bolta' 

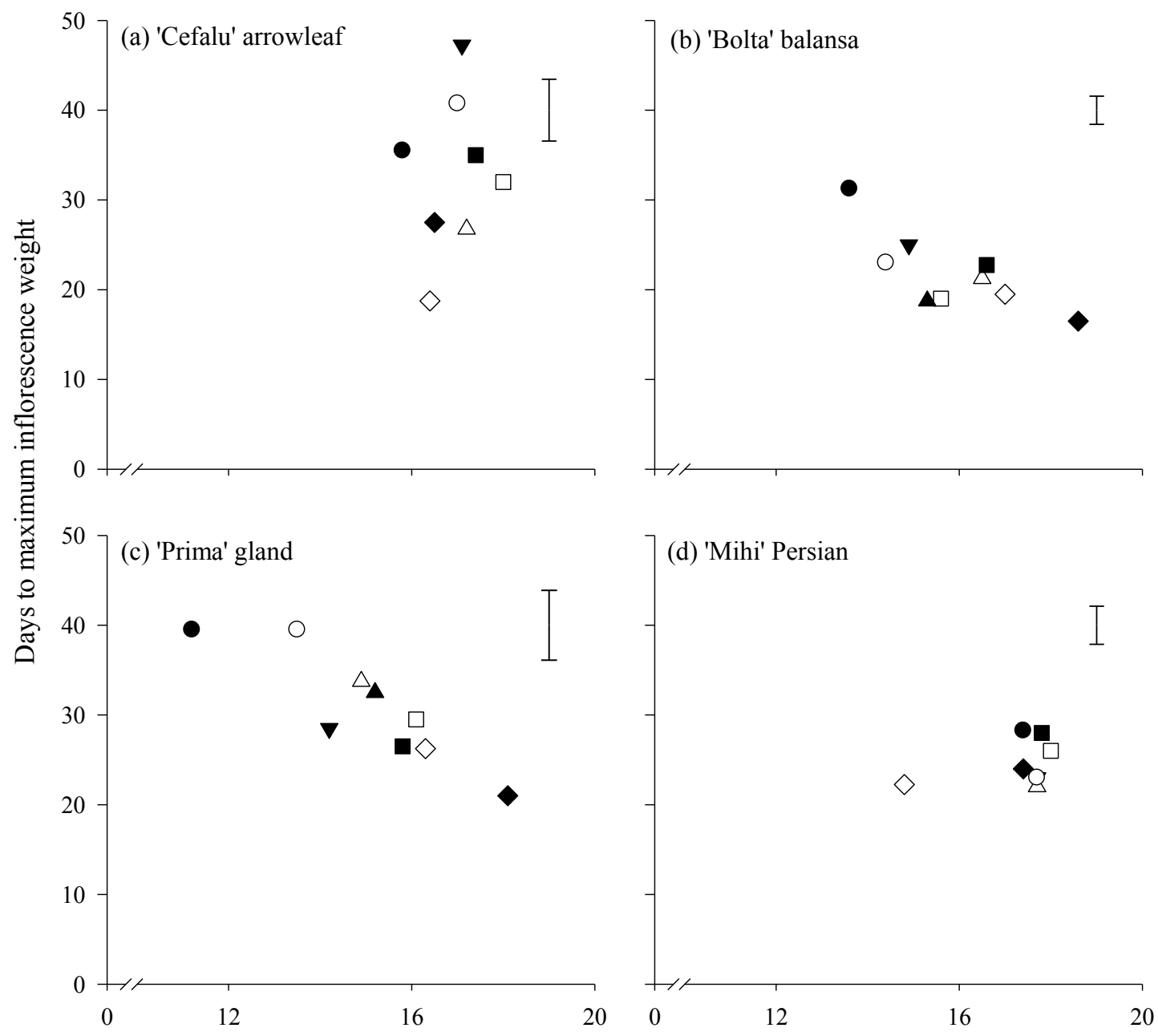

\section{Mean air temperature $\left({ }^{\circ} \mathrm{C}\right)$}

Figure 3 Days to maximum inflorescence weight for (a) 'Cefalu' arrowleaf, (b) 'Bolta' balansa, (c) 'Prima' gland and (d) 'Mihi' Persian clover against mean daily temperature from pollination (stage 6) to maximum inflorescence weightsown on 10 different dates at Lincoln University, Canterbury, New Zealand on 26 Feb $10(\mathbf{0}), 30$ Mar $10(0)$ ), 4 May 10 ( $\mathbf{\nabla}), 3$ Jun $10(\triangle)$, 7 Jul $10(\square), 14$ Aug $10(\square), 25$ Sep $10(\diamond)$, 9 Nov $10(\diamond), 20$ Dec $10(\mathbf{\Delta})$. Error bars represent the maximum standard error of the mean.

balansa, $256^{\circ} \mathrm{C}$ days for 'Prima' gland and $425^{\circ} \mathrm{C}$ days for 'Mihi' Persian clover (Figure 2). The differences in thermal time requirements for physiological maturity across 10 sowing dates for these four species were reported previously by Nori et al. (2014). This event occurred when $50 \%$ of seeds turned red/brown (stage 12) in 'Cefalu' arrowleaf, $100 \%$ of pods were yellow (stage 13) in 'Bolta' balansa, seeds were hard and $100 \%$ of seeds were yellow (stage 12) in 'Prima' gland and pods turned brown and the first sign of seeds changing colour (stage 11) in 'Mihi' Persian clover in accordance with the visual reproductive development scale (Tables 2-5).

\section{Discussion}

The time to first flower in these four annual clovers was affected by the photoperiod at the time of crop emergence (Nori et al. 2014). In most sowing dates (February-November), these species only flowered when day length was increasing in spring and summer (Table 1). As these are cross-pollinated species, flowering at these seasons gives favourable conditions (warm temperatures and low moisture) for pollinating insects, thus promotes seed development process. Therefore, it is not recommended to sow annual clovers in summer, particularly between December 
and January. This is because these plants will flower in autumn, but the inflorescence will not develop into seed but decay instead due to wet and cold conditions (Table 7). In all species, inflorescence weight was the heaviest when seed filling occurred during mid-spring to early summer and was associated with autumn sown plants. For spring sown plants that experienced seed filling during summer, the warmer ambient temperature which coincided with summer moisture deficits accelerated plant senescence. This shortened the duration of seed filling (Figure 3) in days which would reduce total light interception and therefore photosynthate supply, and as a consequence produce the lower inflorescence weights. The maximum weight of inflorescence marks the end of seed filling. The seeds are physiologically mature at this point and ready to be harvested, grazed to open the sward and to spread faeces, or allowed to drop in a pasture situation. The visual reproductive development scale was created as tools to help farmers to recognise the sign of seed maturity to ensure some regeneration of seed in the following seasons. It is suggested that when half of the seeds have turned red/brown in arrowleaf (stage 12, Table 2), pods become yellow in balansa (stage 13, Table 3), gland clover seeds are yellow and hard (stage 12, Table 4), and the first sign of seed colour change in Persian clover (stage 11, Table 5) is an appropriate time for harvest/grazing. Quantifying duration of seed development in thermal time provides a uniform measurement which can be applied over a broad range of climatic conditions. For example, 'Mihi' Persian clover required $425{ }^{\circ} \mathrm{C}$ days from full flower (peak flowering) to physiological maturity (maximum inflorescence weight). Translated into calendar days, this means 'Mihi' Persian clover seeds would take 28 days to mature if the average daily temperature was a constant $15^{\circ} \mathrm{C}$. Based on long term mean temperature data, a theoretical chronological time to seed harvest following peak flowering can be estimated for a range of sites in New Zealand (Table 8). Following physiological maturity, grazing can resume to remove top growth and open up the sward. The bare ground will assist seed softening (Quinlivan 1965), thus increase the chances of seedling regeneration (Craig \& Ballard 2000; Monks et al. 2008) in the next season. Small seeded annual clovers consumed by grazing livestock are expected to pass through the animal gut unharmed and return to the soil via faeces (Edward et al. 1998; Russi et al. 1992). This method of seed dispersal would

Table 8 Predicted chronological time (days) to seed harvest following peak flowering in 'Cefalu' arrowleaf, 'Bolta' balansa, 'Prima' gland and 'Mihi' Persian clovers at four locations in New Zealand (days calculated from NIWA meteorological data, using $a T_{b}=0^{\circ} \mathrm{C}$ for arrowleaf and Persian, $T_{b}=5.2^{\circ} \mathrm{C}$ for balansa and $T_{b}=4.3^{\circ} \mathrm{C}$ for gland clover).

\begin{tabular}{|c|c|c|c|c|c|c|}
\hline \multirow[t]{2}{*}{ Species } & \multirow[t]{2}{*}{ Location } & \multicolumn{5}{|c|}{ Date of peak flowering } \\
\hline & & 1 Oct & 1 Nov & 1 Dec & 1 Jan & $1 \mathrm{Feb}$ \\
\hline \multirow[t]{4}{*}{ 'Cefalu'arrowleaf } & Napier & 48 & 32 & 25 & 21 & 14 \\
\hline & Blenheim & 56 & 36 & 27 & 22 & 16 \\
\hline & Lincoln & $-{ }^{*}$ & 39 & 30 & 24 & 17 \\
\hline & Lake Tekapo & $-{ }^{*}$ & 46 & 34 & 26 & 19 \\
\hline \multirow[t]{4}{*}{ 'Bolta'balansa } & Napier & 13 & 11 & 10 & 9 & 10 \\
\hline & Blenheim & 15 & 13 & 11 & 10 & 11 \\
\hline & Lincoln & 16 & 14 & 12 & 11 & 12 \\
\hline & Lake Tekapo & 21 & 17 & 14 & 12 & 13 \\
\hline \multirow[t]{4}{*}{ 'Prima' gland } & Napier & 18 & 16 & 14 & 13 & 13 \\
\hline & Blenheim & 21 & 18 & 16 & 14 & 15 \\
\hline & Lincoln & 23 & 20 & 17 & 15 & 16 \\
\hline & Lake Tekapo & 29 & 23 & 19 & 17 & 17 \\
\hline \multirow[t]{4}{*}{ ‘Mihi’ Persian } & Napier & - & - & 23 & 22 & 22 \\
\hline & Blenheim & - & - & 26 & 24 & 24 \\
\hline & Lincoln & - & - & 28 & 26 & 27 \\
\hline & Lake Tekapo & - & - & 32 & 28 & 29 \\
\hline
\end{tabular}

Note: 'It is unlikely that 'Cefalu' arrowleaf clover grown in Lincoln and Lake Tekapo will flower as early as September because temperatures in these locations are much colder. 'Mihi' Persian clover requires a specific photoperiod between 15.4 and 16.6 hours to flower (Nori et al. 2014). This means that 'Mihi' Persian clover will not flower until mid-November. 
appear the most effective for arrowleaf, gland and Persian clovers, to ensure their seeds are shed on the ground, because their seeds do not shatter upon burst pods (Nori 2013). Knowing the duration and the endpoint of seed development for each clover species will enable farmers to decide the time of seed harvesting, the time grazing can be resumed, and the time for preparation of seeds for pasture regeneration in the following season.

\section{ACKNOWLEDGEMENTS}

This project was funded by Lincoln University and Beef + LambNZ through their Pastoral 21 programme. Dr H. Nori acknowledges Ministry of Higher Education Malaysia for her PhD scholarship.

\section{REFERENCES}

Clapham, W.M.; Barnes, S.L. 1990. Development and maturation of white lupine seed. Agronomy Journal 82:707-710. DOI: 10.2134/agronj1990.0002196200 $8200040012 x$.

Craig, A.D.; Ballard, R.A. 2000 Balansa clover (Trifolium michelianum) - a forage legume for temperate pastures. Cahiers Options Mediterraneenes 45: 177-180.

Davies, S.; Williams, W. 1986. Development of reproductive structures in grain legumes: the growth, cell structure and maturation of pods and seeds. Experimental Agriculture 22:105-115.

Deunff, Y.L.; Rachidian, Z. 1988. Interruption of water delivery at physiological maturity is essential for seed development, germination and seedling growth in pea (Pisum sativum L.). Journal of Experimental Botany 39:1221-1230. DOI: 10.1093/jxb/39.9.1221.

Edward, A.Y.; Ewing, M.A.; Revell, C.K. 1998. Fate of serradella, medic and biserrula seeds in pods ingested by sheep. pp. 199-202 In: Proceedings of the 9th Australia Agronomy Conference, Wagga Wagga, New South Wales.Eds. Michalk, D.L.; Pratley, J.E.

Hyde, E.O.C. 1950. Studies on the development of white clover seed. Proceedings of the New Zealand Grassland Association 12:101-107.

Jones, C.A.; Kiniry, J.R. 1986. CERES-Maize: A simulation model of maize growth and development. Texas A\&M University Press: College Station, TX.
Knott, C.M. 1987. A key for stages of development of the pea (Pisum sativum). Annals of Applied Biology 111:233-245. DOI: $10.1111 / \mathrm{j} .1744-7348.1987$. tb01450.x.

Monks, D.P. 2009. The vegetative and reproductive development of balansa clover. PhD Thesis, Lincoln University, New Zealand.

Monks, D.P.; Moot, D.J.; Smith, M.C.; Lucas, R.J. 2008. Grazing management for regeneration of balansa clover in a cocksfoot pasture. Proceedings of the New Zealand Grassland Association 70:233-238.

Munsell, A.H. 1977. Munsell colour charts for plant tissues. 2nd edition. Macbeth Division of Kollmorgen Corporation, Baltimore, USA.

Nori, H.; Moot, D.J.; Monks, D.P.; Black, A.D.; Lucas R.J. 2014. Reproductive development of four top flowering annual clovers. Crop and Pasture Science 65:388-399. DOI: http://dx.doi.org/10.1071/CP13329.

Nori, H.N. 2013. The development and growth of annual clovers for use in dryland pasture. $\mathrm{PhD}$ thesis. Lincoln University, Canterbury, New Zealand.

Quinlivan, B. 1965. The influence of the growing season and the following dry season on the hardseeedness of subterranean clover in different environments. Australian Journal of Agricultural Research 16:277291. DOI: http://dx.doi.org/10.1071/AR9650277.

Russi, L.; Cocks, P.S.; Roberts E.H. 1992. The fate of legume seeds eaten by sheep from a Mediterranean grassland. Journal of Applied Ecology 29:772-778. DOI: $10.2307 / 2404487$.

Samarah, N.H. 2006. Effect of air-drying immature seeds in harvested pods on seed quality of common vetch (Vicia sativa L.). New Zealand Journal of Agricultural Research 49:331-339. DOI: 10.1080/00288233.2006.9513723.

Siddique, A.B.; Wright, D. 2003. Effects of time of harvest at different moisture contents on seed fresh weight, dry weight, quality (viability and vigour) and food reserves of peas (Pisum sativum L.). Asian Journal of Plant Sciences 2:983-992. DOI: 10.3923/ ajps.2003.983.992

Zadoks, J.C.; Chang, T.T.; Konzak, C.F. 1974. A decimal code for the growth stages of cereals. Weed Research 14:415-421. DOI: 10.1111/j.13653180.1974.tb01084.x. 